\title{
AKTIVITAS EKSTRAK METANOL RIMPANG KUNYIT PUTIH (Curcuma zedoaria Rosc.) SEBAGAI HIPOLIPIDEMIA PADA TIKUS WISTAR PUTIH OBESITAS DENGAN DIET TINGGI KOLESTEROL
}

\author{
A. Intan Saridewi*, N. W. Bogoriani, dan P. Suarya \\ Program Studi Kimia FMIPA Universitas Udayana, Bukit Jimbaran, Bali \\ *Email : aintan12blue@gmail.com
}

\begin{abstract}
ABSTRAK
Obesitas merupakan keadaan akumulasi lemak yang tidak normal. Obesitas berdampak pada berbagai macam penyakit degeneratif yaitu diabetes militus, hiperkolesterolimia, aterosklerosis, dislipidemia, dan penyakit jantung koroner. Kunyit putih (Curcuma zedoaria Rosc.) diketahui mengandung senyawa polifenol (kurkuminoid) yang dapat berperan sebagai antioksidan. Penelitian ini bertujuan untuk mengetahui aktivitas ekstrak rimpang kunyit putih pada profil lipid tikus wistar obesitas dengan diet tinggi kolesterol serta mengetahui golongan senyawa metabolit sekunder yang terkandung dengan uji fitokimia. Uji Aktivitas ekstrak rimpang kunyit putih menggunakan tikus wistar betina obesitas yang diberi diet tinggi kolesterol sebagai kontrol positif dan pemberian ekstrak dengan dosis 35 dan $70 \mathrm{mg} / \mathrm{kgBB} / \mathrm{hari}$ sebagai perlakuan serta tikus wistar betina normal yang diberi diet standar sebagai kontrol negatif. Hasil analisis menunjukkan bahwa ekstrak metanol rimpang kunyit putih pada dosis 35 dan $70 \mathrm{mg} / \mathrm{kgBB} / \mathrm{hari}$ mampu menurunkan kadar trigliserida, kolesterol LDL, dan kolesterol total dan pada dosis $70 \mathrm{mg} / \mathrm{kgBB} /$ hari dapat meningkatkan kadar kolesterol HDL secara signifikan $(\mathrm{p}<0,05)$. Hal ini disebabkan oleh adanya golongan senyawa flavonoid, alkaloid, fenolat, terpenoid dan saponin yang positif terkandung dalam ekstrak rimpang kunyit putih dari uji fitokimia. Berdasarkan hal tersebut, ekstrak rimpang kunyit putih pada dosis $70 \mathrm{mg} / \mathrm{kgBB} /$ hari mampu berperan sebagai hipolipidemia pada tikus wistar obesitas dengan diet tinggi kolesterol.
\end{abstract}

Kata kunci : ekstrak metanol rimpang kunyit putih, trigliserida, kolesterol LDL, kolesterol HDL, kolesterol total, hipolipidemia

\begin{abstract}
Obesity is an abnormal fat accumulation that can trigger the appearance of various degenerative diseases, such as diabetes militus, hypercholesterolemia, atherosclerosis, dyslipidemia, and coronary heart disease. White turmeric (Curcuma zedoaria Rosc.) shows a strong antioxidant activity due to the existence of polyphenol compound (curcuminoid). This research aimed to reveal the potential impact imposed by the extract of white turmeric rhizome on the lipid profile of high-cholesterol-induced obese rats (acts as hypolipidemia) and also to establish the type of secondary metabolic compound in the methanol extract of white turmeric rhizome by phytochemical test. The experiment was performed by using obese female wistar rats fed with a high cholesterol diet as the positive control and given methanol extract of white turmeric rhizome at doses 35 and $70 \mathrm{mg} / \mathrm{kg}$ b.w. /day and also normal female wistar rats fed with standart/normal diet as the negative control. The results showed that the methanol extract of rhizome of white turmeric at doses 35 and $70 \mathrm{mg} / \mathrm{kg}$ b.w./day could reduce effectively the triglycerides, LDL cholesterol, and the total cholesterol of the subjects. Furthermore, the later dosage (i.e., $70 \mathrm{mg} / \mathrm{kg}$ b.w./day) was also proved to be effective in increasing HDL cholesterol significantly $(\mathrm{p}<0,05)$. This was due to the existence of several types of compounds, proven by the phytochemical test, which were positively contained in the extract i.e., flavonoid, alkaloid, phenolate, terpenoid, and saponin. Based on this study, it can be seen that rhizome extract of white turmeric at a dose of $70 \mathrm{mg} / \mathrm{kg}$ b.w./day could play a role as a hypolipidemia in high-cholesterol-induced obese rats.
\end{abstract}

Keywords: methanol extract of white turmeric rhizome, triglycerides, cholesterol LDL, cholesterol HDL, total cholesterol, hypolipidemia

\section{PENDAHULUAN}

Obesitas merupakan keadaan dimana terjadi akumulasi lemak yang tidak normal pada jaringan adiposa atau sering dikatakan sebagai gangguan metabolik (Chadha et al., 2006). Keadaan obesitas sering disertai dengan kenaikan atau penurunan fraksi lipid yang dapat meningkatkan resiko terjadinya diabetes militus, hiperkolesterolimia, aterosklerosis, dislipidemia, 
dan penyakit jantung coroner. Individu yang mengalami obesitas terutama obesitas sentral akan mempunyai gambaran peningkatan kadar lipoprotein dalam darah yang mengacu terhadap keadaan dislipidemia. Abnormalitas lipid dan lipoprotein terhadap individu penderita obesitas yaitu berupa kenaikan kadar kolesterol total, trigliserida, kolesterol LDL (Low Density Lipoprotein), dan penurunan kadar kolesterol HDL (High Density Lipiprotein) (WHO, 2001)

Ateroskleriosis adalah penebalan dinding pembuluh darah arteri akibat pegendapan lemak yang dapat menjadi faktor terjadinya penyakit jantung koroner dan dislipidemia. Penyakit dislipidemia ditandai dengan peningkatan kadar kolesterol LDL dan penurunan kadar kolesterol HDL (kelainan fraksi lipid). Selain itu jika kadar kolesterol dalam hati tinggi atau berlebih dalam waktu lama maka dapat mengganggu metabolisme kolesterol dalam hati sehingga dapat mempercepat proses pembentukan plak di dinding pembuluh darah (Bogoriani et al., 2015)

Pencegahan dan pengobatan terjadinya obesitas serta timbulnya penyakit degeneratif lainnya seperti dislipidemia, dapat dilakukan dengan cara menurunkan kadar kolesterol dalam tubuh dengan mengkonsumsi makanan rendah lemak (Bogoriani et al,. 2018)

Pencegahan lainnya dapat dilakukan dengan cara mencegah penyerapan kolesterol dan menurunkan sintesis kolesterol dalam tubuh (endogen), serta konsumsi obat alami atau obat tradisional sehingga kadar kolesterol darah berada pada batas normal. Salah satu obat alami penurun kadar kolesterol dalam darah adalah ekstrak kunyit putih (Charlton-Menys and Durrington, 2007).

Kunyit putih (Curcuma zedoaria Rosc.) adalah salah satu tanaman yang termasuk keluarga Zingiberaceae yang sangat penting terutama rimpang. Curcuma zedoaria Rosc., mengandung senyawa utama yaitu kurkuminoid yang termasuk dalam golongan senyawa polifenol, minyak atsiri, serta polisakarida. Aktivitas farmakologik dari kunyit putih dilaporkan mempunyai efek antioksidan, antimikroba, antiradang, antikanker, hepatoprotektif, dan insektisida (Windono et ai., 2002).

Senyawa kurkuminoid pada kunyit putih yaitu berupa kurkumin, demetoksi kurkumin, dan bis- demektoksi kurkumin. Beberapa penelitian menyatakan bahwa senyawa kurkumin dan turunanya dapat berperan sebagai antioksidan serta senyawa demetoksi kukurmin berperan dalam meningkatkan sekresi asam empedu, dimana asam empedu akan membentuk molekul misel dengan demetoksi kukurmin. Hal tersebut dapat mengurangi interaksi asam empedu dengan lemak dan menyebabkan tidak terjadinya pemecahan lemak oleh lipase sehingga penyerapan kolesterol berkurang serta meningkatkan ekskresi lemak ke feses. Selain itu, interaksi tersebut dapat memperbaiki fungsi hati dan tampilan limfosit darah. Aktivitas zat kurkumin juga berperan sebagai antioksidan yang mampu mencegah pembentukan kolesterol LDL menjadi LDL teroksidasi. (Wientarsih, 2002).

Berdasarkan latar belakang di atas, maka pada penelitian ini dilakukan uji aktivitas ekstrak metanol rimpang kunyit putih (Curcuma zedoaria Rosc.) sebagai hipolipidemia pada tikus wistar putih obesitas yang diberi diet tinggi kolesterol serta dilakukan uji fitokimia untuk mengetahui golongan senyawa yang terdapat dalam ekstrak rimpang kunyit putih.

\section{METODE PENELITIAN}

\section{Bahan}

Rimpang Kunyit Putih (Curcuma zedoaria Rosc.), metanol 96\%, $\mathrm{HCl}$ pekat, serbuk $\mathrm{Mg}$, $\mathrm{NaOH}$, serbuk iodin, kalium iodida, $\mathrm{HgCl}_{2}, \mathrm{KI}$, asam asetat anhidrat, $\mathrm{H}_{2} \mathrm{SO}_{4}$ pekat, $\mathrm{FeCl}_{3}, \mathrm{NaCl}$, standar kolesterol, reagen Sekisui Medical Cholesterol, reagen Sekisui Medical Trigliserida, reagen Sekisui Medical Cholesterol HDL, tikus wistar putih betina, pakan standar, pakan tinggi kolesterol, dan aquades.

\section{Peralatan}

Peralatan yang digunakan dalam penelitian ini antara lain : instrument ERBA XL100 , spatula, blender, toples kaca, peralatan gelas, tabung serum, test tube (tabung sentrifugasi), alat sentrifugasi, corong, rotary vacum evaporator, neraca analitik, kain kasa, aluminium foil, pipet tetes, penangas air, alat sonde, sarung tangan, dan masker. 


\section{Cara Kerja \\ Preparasi Sampel}

Sampel rimpang Kunyit Putih (Curcuma zedoaria Rosc.) diambil dari daerah Sukosari, Jember Jawa Timur yang selanjutnya dicuci dan dibersihkan dari tanah dengan air kemudian dihaluskan dengan cara diblender.

\section{Ekstraksi Rimpang Kunyit Putih}

Rimpang kunyit putih segar yang telah dihaluskan dimaserasi dengan metanol $96 \%$ selama \pm 24 jam yang selanjutnya dipekatkan dengan vacuum rotaty evaporator.

\section{Skreening Fitokimia}

Ekstrak metanol rimpang kunyit putih diuji fitokimia terhadap senyawa metabolit sekunder yaitu alkaloid menggunakan pereaksi Wagner dan Meyer, flavonoid menggunakan pereaksi Wilstater dan $\mathrm{NaOH}$, fenolat menggunakan pereaksi $\mathrm{FeCl}_{3}$, terpenoid dan steroid menggunakan pereaksi LiebermanBurchard, serta saponin menggunakan $\mathrm{HCl}$.

\section{Uji Aktivitas Rimpang Kunyit Putih}

Penelitian ini merupakan experimental laboratorik menggunakan metode Randomized Posttest Only Control Group Design. Sebanyak 24 ekor tikus wistar putih betina diadaptasi dan dibagi menjadi beberapa kelompok yaitu kelompok kontrol negatif, kontrol positif, dan kelompok perlakuan. Masing-masing kelompok terdiri dari 6 ekor tikus. Kelompok kontrol positif dan kontrol perlakuan diberi pakan tinggi kolesterol hingga mencapai kondisi obesitas (Indeks Lee > 0,3). Selanjutnya masing-masing kelompok diberi perlakuan secara per oral dengan ketentuan sebagai berikut :

a. Kelompok Kontrol Negatif (K) adalah kelompok yang tidak diberi perlakuan ekstrak metanol rimpang kunyit putih dan pakan tinggi kolesterol (kontrol normal). Kelompok ini hanya diberi pakan normal.

b. Kelompok Kontrol Posisitf $\left(\mathrm{P}_{1}\right)$ adalah kelompok yang tidak diberi perlakuan ekstrak metanol rimpang kunyit putih. Kelompok ini diberi pakan tinggi kolesterol saja.

c. Kelompok Perlakuan $\left(\mathrm{P}_{2}\right)$ adalah kelompok yang diberi pakan tinggi kolesterol dan perlakuan ekstrak rimpang kunyit putih dengan dosis $35 \mathrm{mg} / \mathrm{kgBB} /$ hari per hari.

d. Kelompok Perlakuan $\left(\mathrm{P}_{3}\right)$ adalah kelompok yang diberi pakan tinggi kolesterol dan perlakuan ekstrak rimpang kunyit putih dengan dosis $70 \mathrm{mg} / \mathrm{kgBB} / \mathrm{hari}$ per hari.

Perlakuan dilakukan selama 30 hari dan selama perlakuan berat badan tikus ditimbang setiap minggu. Setelah perlakuan selama 30 hari selesai dilakukan, tikus dipuasakan selama \pm 12 jam untuk selanjutnya diambil darahnya melalui orbital mata. Sampel darah disentrifugasi sehingga diperoleh serum darah yang kemudian dilakukan pemeriksaan kadar kolesterol total, trigliserida, kolesterol HDL dan kolesterol LDL.

\section{Analisis Profilipid Tikus Wistar}

Kadar trgliserida, kolesterol HDL dan kolesterol total diuji menggunakan prinsip kerja spektrofotometri dengan instrumen ERBA XL100. Reagen yang digunakan adalah reagen Sekisui Medical Cholesterol, reagen Sekisui Medical Trigliserida, dan reagen Sekisui Medical Cholesterol HDL. Kadar kolesterol LDL dihitung dengan rumus yang disusun oleh Fridewald et.,al, jika trigliserida $<400 \mathrm{mg} / \mathrm{dL}$ sebagai berikut :

LDL $=$ Total Kolesterol $-($ HDL Kolesterol $+1 / 5$ Trigliserida)

\section{Analisis Data}

Data hasil penelitian yang diperoleh dianalisis secara statistik dengan program SPSS 20. Seluruh data diuji normalitas dengan uji Kolmogorov - Smirnov dan dilanjutkan dengan uji analisis varian (One Way ANOVA) dengan uji LSD (Least Square Defference) dan Uji Duncan untuk mengetahui pengaruh pemberian ekstrak rimpang kunyit putih terhadap profil lipid tikus. Apabila data tidak homogen maka dianalisis dengan uji Tamhane.

\section{HASIL DAN PEMBAHASAN}

\section{Ekstraksi Rimpang Kunyit Putih}

Ekstraksi dilakukan dengan metode maserasi (perendaman) menggunakan pelarut metanol yang dapat mengekstraksi senyawa polar hingga senyawa non polar. Proses ekstraksi dilakukan dengan menggunakan rimpang kunyit putih segar sebanyak $1,5 \mathrm{~kg}$. Proses maserasi dilakukan pengulangan sebanyak dua kali agar senyawa-senyawa terkandung dalam rimpang kunyit putih dapat terekstrak sempurna. Filtrat hasil maserasi dipekatkan dengan vacuum rotary evaporator sehingga diperoleh ekstrak kental metanol rimpang kunyit putih yang berwarna 
coklat sebanyak 48,34 gram dengan hasil rendemen dari maserasi sebesar $3,22 \%$ (b/b). Ekstrak metanol rimpang kunyit putih tersebut Tabel 1. Hasil Uji Fitokimia Ekstrak Metanol Rimpang Kunyit Putih

\begin{tabular}{lll}
\hline Golongan & Pereaksi & Keterangan \\
\hline Flavonoid & Wilstater & Positif (+) \\
& NaOH 10\% & Positif (+) \\
Alkaloid & Wagner & Positif (+) \\
& Meyer & Positif (+) \\
Fenolat & $\mathrm{FeCl}_{3} 1 \%$ & Positif (+) \\
Terpenoid & Lieberman- & Positif (+) \\
& Burchard & \\
Steroid & Lieberman- & Negatif (-) \\
& Burchard & \\
Saponin & Air + dikocok & Positif (+) \\
\hline
\end{tabular}

Pada uji fitokimia ekstrak metanol rimpang kunyit putih menunjukkan hasil positif untuk golongan flavonoid, alkaloid, fenolat, terpenoid, dan saponin, sedangkan menunjukkan hasil negatif untuk golongan steroid. Kunyit putih megandung senyawa kurkumin yang memiliki struktur aromatis dan terdapat ikatan rangkap terkonjugasi yang dapat mengalami proses resonansi serta adanya gugus fenil yang dapat mengkelat logam sehingga mampu menghambat terjadinya peroksidasi lipid atau mampu sebagai antioksidan.

Adanya senyawa polifenol/fenolik dalam ekstrak metanol rimpang kunyit putih dapat berperan sebagai agen antioksidan. Struktur kurkumin dan turunannya yang memiliki gugus fenolik dapat mengubah radikal bebas menjadi bentuk yang lebih stabil (Purba, et al., 2009)

Hasil ini telah sesuai dengan penelitian oleh Himaja, et al. (2010) dan Azam, et al. (2014) yang menyatakan bahwa ekstrak rimpang kunyit putih (Curcuma zedoaria) mengandung senyawa alkaloid, flavonoid, polifenol, terpenoid, tanin, dan saponin.

\section{Hasil Analisis Berat Badan Tikus}

Berdasarkan hasil analisis varian untuk perlakuan kontrol (+) diperoleh $\mathrm{F}_{\text {hitung }}>\mathrm{F}_{(4,25) \text { tabel }}$ $(\mathrm{p}<0,05)$ maka terdapat perbedaan berat badan tikus, artinya bahwa berat badan tikus tiap minggu meningkat. Sedangkan hasil analisis varian untuk perlakuan kontrol (-) diperoleh $\mathrm{F}_{\text {hitung }}<\mathrm{F}_{(4,25) \text { tabel }}(\mathrm{p}>0,05)$ maka tidak terdapat perbedaan berat badan tikus yang berarti bahwa tidak terjadi kenaikan berat badan tikus. Sedangkan hasil analisis varian untuk perlakuan dosis $35 \mathrm{mg} / \mathrm{kgBB} / \mathrm{hari}$ dan $70 \mathrm{mg} / \mathrm{kgBB} /$ hari selanjutnya diuji fitokimia atau skrining fitokimia dengan hasil sebagai berikut (Tabel 1).

diperoleh $\mathrm{F}_{\text {hitung }}<\mathrm{F}_{(4,25) \text { tabel }}(\mathrm{p}>0,05)$ maka tidak terdapat perbedaan berat badan tikus, dimana hal tersebut berarti bahwa tidak terjadi kenaikan berat badan tikus, artinya pemberian ekstrak metanol rimpang kunyit putih mampu menekan kenaikan berat badan tikus, dengan kata lain ekstrak dapat menurunkan berat badan tikus. Secara deskriptif dosis $70 \mathrm{mg} / \mathrm{kgBB} /$ hari lebih baik dalam menurunkan berat badan tikus dibanding dosis $35 \mathrm{mg} / \mathrm{kgBB} / \mathrm{hari}$ setelah minggu ke tiga. (Tabel 2)

\section{Hasil Analisis Profilipid Tikus}

Pada hasil analisis varian menunjukkan bahwa $F_{\text {hitung }}>F_{(4,25)}$ tabel $(p<0,05)$ maka terdapat perbedaan kadar kolesterol total, kadar trigliserida, kolesterol HDL dan kolesterol LDL, artinya bahwa setidaknya ada sepasang perlakuan yang memberikan hasil berbeda. Hasil uji lanjutan yaitu uji LSD (Least Square Defference) dan uji Duncan diperoleh bahwa semua perlakuan menunjukkan kadar kolesterol total, trigliserida, dan kolesterol LDL berbeda, begitu pula pada hasil uji Tamhene untuk kadar kolesterol HDL, dimana perlakuan kontrol (-) dengan kontrol (+), perlakuan kontrol (-) dengan perlakuan dosis $35 \mathrm{mg} / \mathrm{kgBB} /$ hari dan perlakuan kontrol (-) dengan perlakuan dosis 70 $\mathrm{mg} / \mathrm{kgBB} /$ hari, menunjukkan perbedaan bermakna $(\mathrm{p}>0,05)$.

Hasil analisis statistik menunjukkan bahwa perlakuan dosis $35 \mathrm{mg} / \mathrm{kgBB} /$ hari dan dosis $70 \mathrm{mg} / \mathrm{kgBB} /$ hari keduanya memberikan pengaruh terhadap penurunan kadar kolesterol total, trigliserida, dan kolesterol LDL apabila dibandingkan dengan kontrol positif karena nilai $\mathrm{p}>0,05$. Sedangkan perlakuan dosis 35 $\mathrm{mg} / \mathrm{kgBB} /$ hari secara statistik tidak memberikan pengaruh terhadap kenaikan kadar kolesterol HDL apabila dibandingkan dengan kontrol positif tetapi dosis $70 \mathrm{mg} / \mathrm{kgBB} /$ hari memberikan pengaruh terhadap kenaikan kadar kolesterol HDL apabila dibandingkan dengan kontrol positif. Terlihat dalam Gambar 1,2,3, dan 4 bahwa terjadi penurunan serta kenaikan fraksi lipid pada tikus obesitas yang diberi ekstrak metanol rimpang kunyit putih maupun yang tidak.

Penurunan kadar kolesterol total, trigliserida, dan kolesterol LDL dapat disebabkan oleh senyawa antioksidan yang terkandung 
dalam ekstrak metanol rimpang kunyit putih seperti kurkuminoid. Senyawa kurkuminoid dapat mengurangi penyerapan lemak dan meningkatkan ekskresi lemak ke feses sehingga menurunkan kadar kolesterol dalam hati selain itu akan meningkatkan ambilan LDL dalam plasma oleh reseptor LDL, sehingga kadar LDL plasma akan turun (Fikriah et al., 2005).

Tabel 2. Rata-rata Hasil Analisis Berat Badan Tikus

\begin{tabular}{ccccc}
\hline $\begin{array}{c}\text { Minggu } \\
\text { ke- }\end{array}$ & $\begin{array}{c}\text { Kontrol (-) } \\
\text { (gram) }\end{array}$ & $\begin{array}{c}\text { Kontrol (+) } \\
\text { (gram) }\end{array}$ & $\begin{array}{c}\mathbf{3 5} \mathbf{~ m g / k g B B / h a r i} \\
\text { (gram) }\end{array}$ & $\begin{array}{c}\mathbf{7 0} \\
\mathbf{m g} / \mathbf{k g B B} / \mathbf{h a r i} \\
\text { (gram) }\end{array}$ \\
\hline $\mathbf{0}$ & $147.90 \pm 1.77$ & $195.7067 \pm 2.1585$ & $192.7567 \pm 4.4142$ & $192.9917 \pm 4.1063$ \\
$(\mathbf{A w a l})$ & & & & \\
$\mathbf{1}$ & $148.70 \pm 1.49$ & $199.3933 \pm 2.6648$ & $192.1683 \pm 4.3218$ & $192.4650 \pm 4.1050$ \\
$\mathbf{2}$ & $149.82 \pm 1.58$ & $200.8467 \pm 2.1857$ & $191.4783 \pm 4.4819$ & $192.5717 \pm 4.8313$ \\
$\mathbf{3}$ & $150.73 \pm 1.00$ & $201.3183 \pm 4.6054$ & $189.6750 \pm 3.6900$ & $189.8000 \pm 4.7475$ \\
$\mathbf{4}$ & $151.72 \pm 1.06$ & $207.3500 \pm 4.0662$ & $189.0983 \pm 4.0538$ & $188.0867 \pm 4.6680$ \\
\hline
\end{tabular}

Tabel 3 Rata-rata hasil analisis kadar kolesterol total, trigliserida, kolesterol HDL, dan kolesterol LDL serum darah tikus pada perlakuan kontrol (-), kontrol (+), dosis $35 \mathrm{mg} / \mathrm{kgBB} / \mathrm{hari}$, dan dosis 70 $\mathrm{mg} / \mathrm{kgBB} / \mathrm{hari}$

\begin{tabular}{ccccc}
\hline Perlakuan & $\begin{array}{c}\text { Trigliserida } \\
(\mathbf{m g} / \mathbf{d L})\end{array}$ & $\begin{array}{c}\text { HDL } \\
(\mathbf{m g} / \mathbf{d L})\end{array}$ & $\begin{array}{c}\text { LDL } \\
(\mathbf{m g} / \mathbf{d L})\end{array}$ & $\begin{array}{c}\text { Kolesterol } \\
\text { Total }(\mathbf{m g} / \mathbf{d L})\end{array}$ \\
\hline Kontrol (-) & $140.15 \pm 2.58$ & $44.18 \pm 0.314$ & $53.68 \pm 0.31$ & $125.90 \pm 1.97$ \\
Kontrol (+) & $210.68 \pm 2.56$ & $29.25 \pm 2.626$ & $118.91 \pm 2.62$ & $190.30 \pm 3.63$ \\
$\mathbf{3 5} \mathbf{~ m g / K g ~ B B}$ & $165.02 \pm 3.64$ & $35.16 \pm 4.86$ & $82.69 \pm 4.86$ & $150.87 \pm 2.74$ \\
$\mathbf{7 0 ~ \mathbf { ~ m g } / K g ~ B B}$ & $150.93 \pm 3.52$ & $38.65 \pm 2.80$ & $67.08 \pm 2.80$ & $135.92 \pm 3.33$ \\
\hline
\end{tabular}

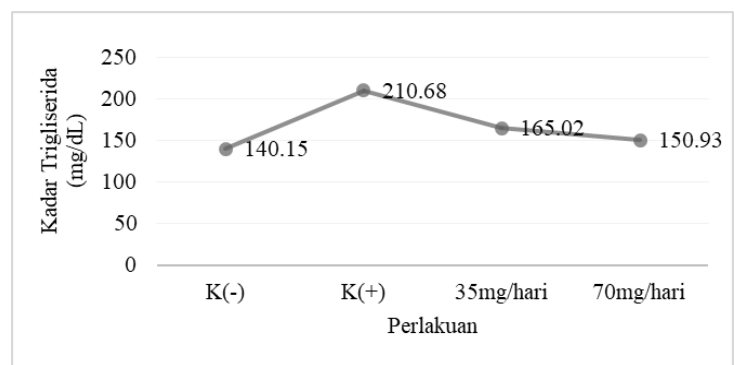

Gambar 1 Grafik rata-rata kadar Trigliserida tikus $(\mathrm{mg} / \mathrm{dL})$

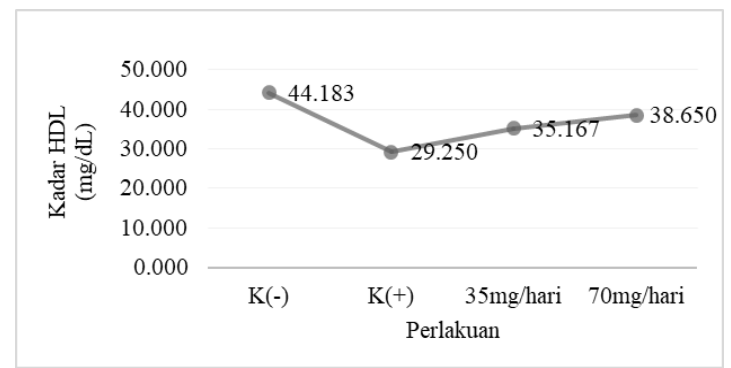

Gambar 2 Grafik rata-rata kadar HDL tikus $(\mathrm{mg} / \mathrm{dL})$ 


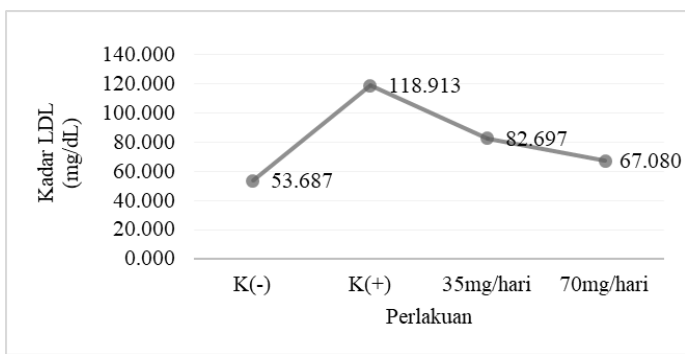

Gambar 3 Grafik rata-rata kadar LDL tikus $(\mathrm{mg} / \mathrm{dL})$

Penurunan kadar kolesterol total, trigliserida, dan kolesterol LDL dapat disebabkan oleh senyawa antioksidan yang terkandung dalam ekstrak metanol rimpang kunyit putih seperti kurkuminoid. Senyawa kurkuminoid dapat mengurangi penyerapan lemak dan meningkatkan ekskresi lemak ke feses sehingga menurunkan kadar kolesterol dalam hati selain itu akan meningkatkan ambilan LDL dalam plasma oleh reseptor LDL,sehingga kadar LDL plasma akan turun (Fikriah et al., 2005).

Kurkumin yang memiliki gugus fenol dan merupakan senyawa aromatis serta adanya gugus fenil, dapat berperan sebagai antioksidan. Kurkumin sebagai antioksidan dapat menangkap ROS (Reactive Oxygen Specie) berlebihan yang menjadi faktor utama terjadinya stress oksidatif (Nurtamin, 2014). Adanya senyawa kurkuminoid tersebut dapat meangsang enzim hepatic cholesterol-7 $\alpha$-hydroxylase untuk meningkatkan perubahan kolesterol hepatik menjadi garam empedu sehingga kadar kolesterol dalam hati berkurang sehingga berdampak pada penurunan kadar kolesterol total. Kenaikan kadar kolesterol HDL dapat disebabkan oleh senyawa kurkuminoid yang dapat meningkatkan apolipoprotein A-I (Apo A-I) yang berperan dalam metabolisme kolesterol HDL terutama pada proses Reverse Cholesterol Transport (RCT) sehingga kolesterol ester pada jaringan perifer dapat diangkut menuju hati dan diubahmenjadi asam empedu (Samy et al, 2014). Selain senyawa kurmuminoid dan turunannya, metabolit sekunder lain yang terkandung seperti flavonoid dapat menjadi agen penurun kadar kolesterol.

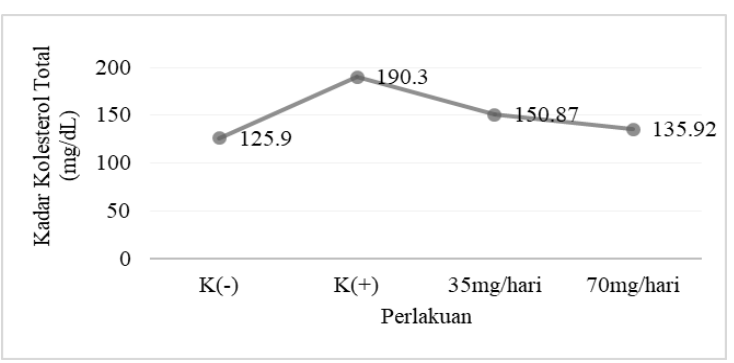

Gambar 4 Grafik rata-rata kadar Kolesterol Total tikus $(\mathrm{mg} / \mathrm{dL})$

\section{SIMPULAN DAN SARAN}

\section{Simpulan}

Berdasarkan hasil penelitian terhadap ekstrak rimpang kunyit putih maka dapat disimpulkan bahwa:

1. Ekstrak metanol rimpang kunyit putih memiliki aktivitas sebagai hipolipidemia pada tikus wistar putih obesitas dengan diet tinggi kolesterol. Ekstrak metanol rimpang kunyit putih dosis $70 \mathrm{mg} / \mathrm{kgBB} / \mathrm{hari}$ dapat menurunkan kadar kolesterol total trigliserida, kolesterol LDL, dan dapat meningkatkan kadar kolesterol HDL.

2. Ekstrak metanol rimpang kunyit putih mengandung golongan senyawa flavonoid, alkaloid, fenolat, terpenoid dan saponin.

\section{Saran}

Perlu dilakukan penelitian lebih lanjut mengenai pengaruh ekstrak metanol rimpang kunyit putih terhadap penurunan berat badan tikus obesitas dan pengaruhnya terhadap profilipid tikus wistar obesitas menggunakan dosis berbeda atau dosis yang lebih tinggi serta aktivitas ekstrak seabagai antihiperglikemik, antidiabetes, dan antiinflamasi.

\section{UCAPAN TERIMAKASIH}

Penulis mengucapkan terima kasih kepada ibu Dr. Dra. Wiwik Susanah Rita, M.Si., bapak I Made Sutha Negara, S.Si., M.Si., dan ibu Dr. Ir. Sri Wahjuni, M.Kes. atas saran dan masukannya. 


\section{DAFTAR PUSTAKA}

Azam, Golam Md., Noman, Shibly Md., AlAmin, Mamun Md., 2014, Phytochemical Screening and Antipyretic Effect of Curcuma zedoaria Rosc. (Zingiberaceae) Rhizome., British Journal of Pharmaceutical Reseacrh, 4(5): 569575.

Bogoriani, N.W., Ariati, N.K., 2018, The activity of Bali Andong Rhizome Extract of Cordyline terminalis Kunt as Hypolipidemia Agent in Wistar Rats with High-Cholesterol Diet, International Journal of Pharmaceutical and Phytopharmaco-logical Reserch, 8(1):75-80.

Bogoriani, N.W., Ratnayani, K., 2015, Efek Berbagai Minyak Pada Metabolisme Kolesterol Terhadap Tikus Wistar, Jurnal Kimia Universitas Udayana, 9(1):53-60.

Chadha, D.S., Singh, G., Kharbanda, P., Vasdev, V., \& Ganjoo R.K., 2006, Anthropometric correlation of lipid profile in healthy aviators., Meta analysis or the published literature., IJASM, 50(2): 32-37.

Charlton-Menys, V. and Durrington, P. N., 2007, Human cholesterol metabolism and therapeutic molecules terhadap kadar kolesterol total, LDL-kolesterol, jumlah F2-Isoprostan, Experimental Physiology-Review Article, 93 (1): $27-$ 42.

Fikriah, I., Kalim, Handono, Drajat, Respati, S., 2005, Pengaruh curcumin dan sel Busa (Foam cell) dinding aorta pada tikus dengan diet aterogenik, Jurnal Kedokteran Brawijaya, 21 (2): 55-62.
Himaja, M., Ranjitna, Anand., Ramana, M.V., Anand, M., Asif, Karigar., 2010, Phytochemical Screening And Antioxidant Activity Of Rhizome Part Of Curcuma zedoaria., International Journal of Reseacrh in Ayurveda \& Pharmacy, 1(2): 414-417.

Nurtamin, K., 2014, Potensi Curcumin untuk Mencegah Aterosklerosis, Jurnal CDK-219, 41(8): 633-635.

Purba, E.R., Martosupono, M., 2009, Kurkumin Sebagai Senyawa Antioksidan, Prosiding Seminar Nasional Sains dan Pendidikan Sains IV, 3:607-621.

Samy, A. Hussein, Yakout, A. El-Senosi, Mohammed, R. Ragah, Mohammed, M, F. Hamman, 2014, Hypolipidemic effect of curcumin in hyoercholesteromic rat Benha, Veterinary Medical Journal, 27 (2): 277-289.

WHO., 2001, General Guidelines for Methodologies on Research and Evaluation of Traditional Medicine, Geneva.

Wientarsih, I., Chakeredza, S., dan Meulen U., 2002, Inffluence of Curcuma (Curcuma Longa Linn) On Lipid Metabolism in rats, Journal of Science food and Agriculture., 4(2): 24-42.

Windono, Tri, Partati, dan Nani, 2002, Curcuma zediaria (Berg.) Rosc.: Kajian Pustaka kandungan kimia dan aktivitas farmakologik, Prosiding Seminar Nasional Tumbuhan Obat Indonesia XX1, Fakultas Farmasi Universitas Surabaya 